\title{
Cobalt Poisoning: A Comprehensive Review of the Literature
}

\author{
Irfan Sheikh \\ Zhejiang University School of Medicine, Hangzhou, Zhejiang, China
}

Corresponding author: Irfan Sheikh, Zhejiang University School of Medicine, Hangzhou, Zhejiang, China, Tel: 4692124350; Fax: 4692124350; Email: irfansheikh2561@yahoo.com

Received date: May 11, 2016; Accepted date: July 21, 2016; Published date: July 28, 2016

Citation: Sheikh I. Cobalt Poisoning: A Comprehensive Review of the Literature. Med Toxicol Clin Forens Med. 2016, 2:2.

Copyright: (c) 2016 Sheikh I. This is an open-access article distributed under the terms of the Creative Commons Attribution License, which permits unrestricted use, distribution, and reproduction in any medium, provided the original author and source are credited.

\section{Abstract}

Cobalt is a chemical element that has been used for centuries recreationally as pigments for colouring, giving the bluish hue to glass. Cobalt Poisoning can be manifested by a wide array of systemic effects. Cobalt poisoning can be seen as a result of super alloys in orthopaedic implants, ionizing radiation, occupational exposure and rarely as a foam stabilizer in beer. Here in we conduct a review of the literature describing the systemic adverse effects of cobalt poisoning along with the respective toxicity levels that have been attributed to multisystem pathology.

\section{Keywords:}

Cobalt; Poisoning; Literature review; Neurotoxicology; Cobalt poisoning; Beer drinkers; Cobalt cardiomyopathy

\section{History of Cobalt}

Cobalt is a heavy metal found on the periodic table as atomic number 27 with an atomic weight of 58.933. The element was discovered by Georg Brandt, a Swedish chemist and mineralogist in $1735[1,2]$. Cobalt compounds have been used for centuries to impart a rich blue colour to glass and ceramics. Cobalt has been detected in Egyptian sculpture and Persian jewellery from the third millennium $B C$, in the ruins of Pompeii (destroyed in 79 $A D)$, and in China dating from the Tang dynasty (618-907 AD) and the Ming dynasty (1368-1644 AD) [3]. Cobalt became the first metal to be discovered since the pre-historical period, during which all the known metals (iron, copper, silver, gold, zinc, mercury, tin, lead and bismuth) had no recorded discoverers [4]. After World War II, the US wanted to be sure it was never short of the ore needed for military cobalt uses (as the Germans had been during that war) and explored for cobalt within the US border. A good supply of the ore needed was found in Idaho near Blackbird canyon in the side of a mountain. The firm Calera Mining Company got production started at the site [5]. Cobalt is known to cause a bluish hue in glass. Brandt attempted to prove the bluish coloration of glass was due to an unknown metal other than bismuth as what was originally postulated during that time. Cobalt is naturally found in many rocks, plants, soil, water, and animals typically in small amounts. In the environment cobalt is found in combination with other elements such as oxygen, sulphur, and arsenic.

\section{Biochemistry, Structure and Uses for Cobalt}

\section{Structure of cobalt}

The structure of cobalt is hexagonal close-packed but transitions to face-centered cubic at temperatures of $450^{\circ} \mathrm{C}$ $\left(842^{\circ} \mathrm{F}\right)$. However, the difference between the two structures is so small that in practice random intergrowth between the two is common [6-8] (Figure 1).

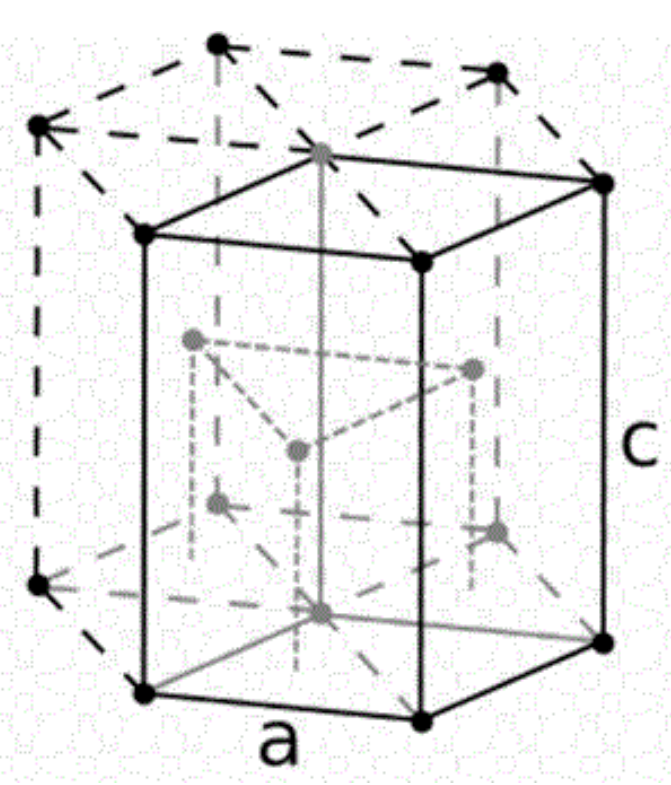

Figure 1 Structure of cobalt.

\section{Biochemical importance of cobalt}

Cobalt is also very important biochemically for homeostasis of DNA, heme, amino acids and fatty acids as cyanocobalamin or Vitamin $B_{12}$. Vitamin $B_{12}$ is a cofactor for homocysteine methyltransferase and methylmalonyl-CoA mutase. 
Homocysteine methyltransferase is important for converting Homocysteine into methionine. The methyl group within methionine becomes activated by the dephosphorylation of ATP forming S-adenosylmethionine (SAM). SAM is an important methyl donor in polyamine synthesis and transmethylation reactions. Methylation reactions are pertinent for myelin maintenance and transmethylation reactions. Thus, a decrease in cyanocobalamin body stores results in decrease methionine and eventually a decrease in SAM.

Although less understood, it is currently believed that reduced levels of SAM (S-adenosylmethionine) and elevated levels of MMA (methylmalonic acid) may contribute to catastrophic neurological disease. These symptoms may present itself as peripheral neuropathy, subacute combined degeneration of the spinal cord, ataxia and even dementia. Dementia is often irreversible if discovered late in the course of the disease. Decrease in cyanocobalamin levels also result in increase in plasma homocysteine levels. Clinically hyperhomocysteinemia can lead to an increase risk of developing thrombosis and atherosclerosis leading to myocardial infarction or stroke like syndromes.

Today, cobalt is used for medical, scientific and recreational purposes. Medically it is used as alloys and superalloys in orthopedic implants [9]. It is used scientifically for chemical reactions as oxidation catalysts [10]. The three main cobalt catalysts include: Hydro-treating, desulphurisation - cobalt molybdenum oxide - CoMOX for oil and gas; Terephthalic acid (TPA)+dimethylterephthalate (DMT) - cobalt acetate +manganese. TPA and DMT are used to manufacture resin for plastic bottles and also to make the new ultra strong plastics used in recording tapes; and OXO catalysts - freshly reduced cobalt metal, carbonyls or cobalt salts (transformed in situ to carbonyl).

\section{Current uses for cobalt}

Recreationally cobalt is used for pigments and colouring giving bluish hue to glass. Other uses for cobalt include wear resistant alloys, prosthetic alloys, magnetic alloys, tool materials (i.e., high speed steels), pigments/ceramics, recording materials (i.e., transducers) and rechargeable batteries (lithium cobalt oxide is widely used in lithium ion batteries)

\section{Toxicities: Review of the Medical Literature}

\section{Toxicity of cobalt}

Toxicity caused by cobalt is extremely rare. The average concentration of cobalt in ambient air in the USA is approximately $0.4 \mathrm{ng} / \mathrm{m}^{3}$. However, cobalt in air will vary substantially from non-source areas to areas with cobalt-related industries. Exposure of cobalt from water varies considerably from location to location but median cobalt concentration in USA drinking water is $<2.0 \mu \mathrm{g} / \mathrm{L}$ [11]. For example, in Canada, the daily cobalt intake of the average adult form drinking water is $\leq 2.6 \mu \mathrm{g}$; this could increase to $10 \mu \mathrm{g}$ for those living in areas with the highest cobalt levels [12-19] (Table 1).

Table 1 Cobalt content of miscellaneous substances.

\begin{tabular}{|c|c|}
\hline Substance/Source & Level \\
\hline Bituminous coal used for power & $6.4 \mathrm{mg} / \mathrm{kg}$ \\
\hline \multicolumn{2}{|l|}{ generation [13] } \\
\hline Coal, United states [11] & $\sim 5 \mathrm{mg} / \mathrm{kg}$ \\
\hline Fly ash [11] & $\sim 25 \mathrm{mg} / \mathrm{kg}$ \\
\hline \multicolumn{2}{|l|}{ MSW Incinerator ash, Mississippi [14] } \\
\hline Fly ash $(n=30)$ & $11.3-13.5 \mu \mathrm{g} / \mathrm{g}$ \\
\hline Bottom ash $(n=30)$ & $65.2-90.3 \mu \mathrm{g} / \mathrm{g}$ \\
\hline Combined ash $(n=8)$ & $24.8-30.5 \mu \mathrm{g} / \mathrm{g}$ \\
\hline \multicolumn{2}{|l|}{ MSW incinerator ash, United States [15] } \\
\hline Fly ash $(n=5)$ & $18.2-54.0 \mu \mathrm{g} / \mathrm{g}$ \\
\hline Bottom ash $(n=7)$ & $13.5-35.1 \mu \mathrm{g} / \mathrm{g}$ \\
\hline Combined ash $(n=8)$ & $11.2-43.4 \mu \mathrm{g} / \mathrm{g}$ \\
\hline \multicolumn{2}{|l|}{ Compost, Toronto [16] } \\
\hline Residential compost & $8.1,3.2-12 \mathrm{mg} / \mathrm{kg}$ \\
\hline Greenhouse finished compost & $6.1 \pm 1.03$ \\
\hline Sewage sludge & \\
\hline
\end{tabular}




\begin{tabular}{|c|c|}
\hline 16 large US cities [17] & $11.3,6.08-29.1 \mathrm{mg} / \mathrm{kg}$ \\
\hline 32 US cities [15] & $7.2,2.4-30.1 \mathrm{mg} / \mathrm{kg}$ \\
\hline Cow manure (comparison) [15] & $6.1 \mathrm{mg} / \mathrm{kg}$ \\
\hline Miscellaneous soil amendments [19] & $3.55,3.57 \mathrm{mg} / \mathrm{kg}$ \\
\hline Compost & $3.24,0.68 \mathrm{mg} / \mathrm{kg}$ \\
\hline Diammonium phosphate & $0.33 \mathrm{mg} / \mathrm{kg}$ \\
\hline Dolomite & $2.23 \mathrm{mg} / \mathrm{kg}$ \\
\hline Manure & $0.78,3.38 \mathrm{mg} / \mathrm{kg}$ \\
\hline Monoammonium phosphate & $19.6 \mathrm{mg} / \mathrm{kg}$ \\
\hline Rock phosphate, Tilemsi & $<0.08 \mathrm{mg} / \mathrm{kg}$ \\
\hline Rock phosphate, North Carolina & $4.10 \mathrm{mg} / \mathrm{kg}$ \\
\hline Sewage sludge, Austinite & $4.07 \mathrm{mg} / \mathrm{kg}$ \\
\hline Sewage Sludge, Milorganite & $6.61,2.24 \mathrm{mg} / \mathrm{kg}$ \\
\hline Triple superphosphate & $8.7-12.9 \mu \mathrm{gg} / \mathrm{g}$ \\
\hline Street dust, New York City [19] & \\
\hline
\end{tabular}

Occupational exposure to cobalt can result from metal mining, smelting, refining, in industries that make or use cutting or grinding tools, or in other industries that produce or use cobalt metal and cobalt compounds. In these occupations the route of exposure is usually inhalational.

Reported effect levels in occupationally exposed humans have ranged from $0.015-0.13 \mathrm{mg} \mathrm{Co} / \mathrm{m}^{3}$. Toxicities of cobalt if inhaled may present with the patient suffering from decreased pulmonary function, increased frequency of cough by irritation of respiratory cilia and possible sensitization of the immune system, respiratory inflammation, and pulmonary fibrosis. The proposed mechanism of inhalational exposure may result from generation of oxidants and free radical damage.

Cobalt toxicity can present with haematological, cardiovascular, immunological, gastrointestinal, endocrinological, dermatological, ophthalmological and neurological effects.

\section{Haematological effects}

Haematological effects caused by Cobalt are thought to be due to the inhibition of heme synthesis in vivo by acting upon at least two different sites in the biosynthetic pathway. This inhibitory activity might result in the formation of cobalt protoporphyrin rather than heme. Cobalt may also stimulate haeme oxidation in many organs due to the induction of heme oxygenase and is believed to stimulate EPO increase by acting on a heme-containing protein [20].

Table 2 Cardiac effects of cobalt.

\section{Cardiovascular effects}

Cardiovascular effects caused by Cobalt toxicity have been reported in many studies [21-26]. Cobalt Sulfate was used in Quebec, Canada as a foam stabilizer in beer [21-24] with the average intake of $0.04 \mathrm{mg} \mathrm{Co} / \mathrm{kg} /$ day to $0.14 \mathrm{mg} \mathrm{Co} / \mathrm{kg} /$ day [25, 26] for a period of years. It was known as beer-drinkers cardiomyopathy and appeared similar to the dilated cardiomyopathy caused by Thiamine deficiency (wet beriberi). However, the onset of beer-cobalt cardiomyopathy was more acute in comparison to beriberi. Beer-drinkers cardiomyopathy has been reported to have a very high mortality with $40-50 \%$ of patients admitted to the hospital dying within several years of diagnosis and those who survive $23-41 \%$ had abnormal EKG's $[25,26]$. The mechanism for cobalt cardiomyopathy is poorly understood, however it is thought that the accumulation of cobalt in cardiac tissues stimulates carotid-body chemoreceptors, mimicking the action of hypoxia. The molecular destruction of cardiac muscle as studied in rat models is due to a decrease in cardiac enzymes, including manganese-superoxide dismutase, succinate-cytochrome $\mathrm{C}$ oxidase, $\mathrm{NADH}$-cytochrome $C$ reductase, and cytochrome $C$ oxidase, as well as reducing the mitochondrial ATP production rate [27].

The first signs of beer-cobalt cardiomyopathy syndrome were GI effects $[24,28]$ where ingestion of an average of $0.04 \mathrm{mg}$ $\mathrm{Co} / \mathrm{kg} /$ day for a period of years subsequently followed cardiomyopathy. Hepatic injury from cobalt toxicity may result from ischemia secondary to the cardiac effects of cobalt, and/or from excessive alcohol consumption (Cobalt-Beer Drinkers Cardiomyopathy) $[26,28]$ (Table 2). 


\begin{tabular}{|c|c|c|}
\hline \multicolumn{3}{|c|}{ Systemic Effects of Cobalt Exposure } \\
\hline Organ system & Toxicity Levels reported & Reported Effects \\
\hline \multirow{5}{*}{ Pulmonary } & \multirow{5}{*}{$\mathrm{INH} 0.015-0.13 \mathrm{mg} \mathrm{Co} / \mathrm{m}^{3}$} & Pulmonary compromise \\
\hline & & Pulmonary Inflammation \\
\hline & & Granulomatous lung disease [29] \\
\hline & & Restrictive Lung Disease, Pulmonary Fibrosis, Fibrosing Alveolitis [30] \\
\hline & & Asthma like syndrome [31] \\
\hline Hematological & $\mathrm{PO} \sim 1 \mathrm{mg}$ Co/kg-day [20] & $\begin{array}{c}\text { Increased levels of erythrocytes and hemoglobin, i.e., polycythemia (levels normalizes 9-15 days } \\
\text { after cessation) }\end{array}$ \\
\hline \multirow{11}{*}{ Cardiovascular } & \multirow{11}{*}{$\begin{array}{l}\mathrm{PO} 0.04 \mathrm{mg} \mathrm{Co} / \mathrm{kg} / \text { day }[21-24] \text { to } 0.14 \mathrm{mg} \\
\text { Co/kg/day }[25,26]\end{array}$} & Beer-Drinkers Cardiomyopathy [21] \\
\hline & & Sinus tachycardia \\
\hline & & Left Ventricular Failure \\
\hline & & Cardiogenic shock \\
\hline & & Diminished myocardial compliance \\
\hline & & Absence of myocardial response to exercise or \\
\hline & & catecholamine \\
\hline & & Enlarged heart \\
\hline & & Pericardial effusion \\
\hline & & Extensive intracellular changes (changes in the myofibers, mitochondria, glycogen, and lipids) \\
\hline & & $\begin{array}{c}\text { Pathological changes in myocardiaum including proliferative interstitial tissue, swollen muscle } \\
\text { fibers, and focal degeneration). }\end{array}$ \\
\hline \multirow{3}{*}{ Gastrointestinal } & \multirow{3}{*}{ PO 0.04 mgCo/kg/day $[27,28]$} & Nausea \\
\hline & & Vomiting \\
\hline & & Diarrhea \\
\hline \multirow{5}{*}{$\begin{array}{l}\text { Hepatic effects }[26 \text {, } \\
\text { 27] }\end{array}$} & \multirow{5}{*}{$\mathrm{PO} 0.04 \mathrm{mgCo} / \mathrm{kg} / \mathrm{day}$} & Central hepatic necrosis \\
\hline & & Increased Serum Bilirubin \\
\hline & & Increase AST, ALT, LDH \\
\hline & & Increase Creatine Phosphokinase \\
\hline & & Increase Ornithine Carbamyl Transferase, Isocitric Dehydrogenase and Aldolase \\
\hline \multirow{3}{*}{ Endocrine } & \multirow{3}{*}{$\mathrm{PO} 0.066 \mathrm{mgCo} / \mathrm{kg} / \mathrm{day}$} & Histological morphology: irregular follicles, decreased follicular size [32] \\
\hline & & Goiter, hypothyroidism, thyroid hypoplasia [33] \\
\hline & & Thyroid hypertrophy, thyroid hyperplasia, thyroid firmness [34-37] \\
\hline \multirow{2}{*}{ Dermatological } & \multirow{2}{*}{ PO 0.014 mg/kg/day } & Allergic Dermatitis \\
\hline & & Eczema flares [38] \\
\hline \multirow{3}{*}{ Ophthalmological } & $\mathrm{PO} 1.3 \mathrm{mgCo} / \mathrm{kg} / \mathrm{day}$ & Severe visual disturbance (optic atrophy, impaired choroidal perfusion) [39] \\
\hline & \multirow{2}{*}{ Cobalt Super alloy Hip replacement } & $\begin{array}{l}\text { Implant-related chorio-retinal cobalt toxicity [40], patchy degeneration of the photoreceptor-retinal } \\
\text { pigment epithelium (RPE) complex }\end{array}$ \\
\hline & & Toxic retinopathy [41] \\
\hline \multirow{2}{*}{ Immunological } & & Sensitization to cobalt \\
\hline & & Neutropenia [42] \\
\hline Neurological [47] & Serum levels $>0.01 \mathrm{mg}$ & Memory impairment \\
\hline
\end{tabular}




\begin{tabular}{|c|c|c|}
\hline \multirow{2}{*}{} & \multirow{2}{*}{} & Altered mental status \\
\cline { 2 - 3 } & & Deafness, vertigo \\
\cline { 2 - 3 } & Serum levels $>0.01 \mathrm{mg}$ & Seizures, tremors \\
\hline Psychiatric $[47]$ & Depression \\
\hline
\end{tabular}

\section{Radioactive Cobalt}

While there is only stable isotope of cobalt, ${ }^{59} \mathrm{Co}$, there are many radioactive isotopes of cobalt. Of these radioactive isotopes, two are commercially important, ${ }^{60} \mathrm{Co}$ and ${ }^{57} \mathrm{Co} .{ }^{60} \mathrm{Co}$ is produced by irradiating ${ }^{59} \mathrm{Co}$ with thermal neutrons in a nuclear reactor, and is used as a source of gamma rays for sterilizing medical equipment or consumer products, food irradiation, radiation therapy for treating cancer patients and for manufacturing plastics.

For the most part the general population is not exposed to radiate $\mathrm{Co}$, but patients receiving radiation therapy for cancer may be exposed to gamma rays from ${ }^{60} \mathrm{Co}$ source. However, the effect of external exposure to gamma radiation is not unique to ${ }^{60} \mathrm{Co}$, but is similar for all gamma-emitting radio nucleotides. Other groups of people who are at considerable risk for ${ }^{60} \mathrm{Co}$ toxicity include workers at nuclear facilities and workers at nuclear waste storage sites. Exposure to high doses of cobalt radiation has been shown to result in damage of nervous tissue, particularly peripheral nerves.

Some studies where radiotherapy was applied to nasopharyngeal and cervical LN pathologies, patients developed focal necrosis of the frontal lobe [43]. Another study showed patients also receiving ${ }^{60} \mathrm{Co}$ radiotherapy for ALL (head only) developing severe vision disorders and even total blindness [44]. In this study, subsequent histopathology was done on one of the patients demonstrating severe alterations in the optic nerve, including severe atrophy, terminal beading, lack of myelin, and calcifications. Other effects of ${ }^{60} \mathrm{Co}$ radiotherapy include myelopathy, resulting in minimal to mild paralysis [45] and brachial plexus neuropathy, vocal cord paresis [46].

\section{Discussion}

Cobalt is widely dispersed in the environment in low concentrations. It is found in soil, water and cobalt alloys. Current analytical methods fail to determine the specific chemical form of cobalt present in the environment. Thus it is difficult to always be certain of the chemical form of cobalt to which an individual may be exposed or the form of cobalt in hazardous waste sites. For example, the concentration of cobalt in soil varies from about 1 to $40 \mathrm{ppm}(1 \mathrm{ppm}=1$ part of cobalt in a million parts of soil by weight), with an average level of $7 \mathrm{ppm}$; the concentration of cobalt in the air is less than $2 \mathrm{ng}$ ( $1 \mathrm{ng}=$ one billionth part of a gram) per cubic meter $\left(\mathrm{ng} / \mathrm{m}^{3}\right)$; the concentration of cobalt in surface and groundwater in the USA is generally between 1 and $10 \mathrm{ppb}$ (parts of cobalt in 1 billion parts of water); the cobalt level in most drinking water is less than 1-2 ppb [47]. Food is considered the largest source of cobalt intake, where in which the average individual consumes about 11 micrograms of cobalt a day in their diet. Included in these foods is vitamin $B_{12}$, which is found in meat and dairy products. Occupational exposure to cobalt can also be seen in individuals at risk. High-risk occupational exposures include those individuals working in metal mining, smelting and refining industries. In general, risk of acquiring cobalt toxicity from the environment is relatively low due to the minuscule amount of cobalt present. However, those with high-risk occupations, as listed above, should practice appropriate industrial hygiene by using exhaust systems in the workplace and wearing protective clothing.

Although cobalt toxicity is a relatively rare occurrence it should still is noted as a complication of total knee and hip replacement surgical procedures especially when a cobalt alloy is used as the replacement graft. Since the advent of proper brewing techniques "beer-drinkers cobalt toxicity" is also a relatively rare occurrence [21-23]. However, when evaluating patient's cardiomyopathy or interstitial lung disease, especially in patients with past history of knee or hip alloy replacements, one should always consider the possibility of systemic cobalt poisoning and workup should be done. Furthermore, a prospective observational study evaluating the incidence cobalt toxicity in patients with total knee arthroplasty where cobalt was used as the graft should be done. If at most, a cobalt metal laboratory panel should be considered in patients with cobalt alloys to determine the level of exposure and risk of cobalt exposure from such alloys [48].

\section{References}

1. "Georg Brandt" (2009) Encyclopædia Britannica.

2. "Georg Brandt" (2010) Nationalencyklopedin(in Swedish).

3. Cobalt, Encyclopædia Britannica Online

4. Weeks, Elvira M (1932) "The discovery of the elements. III. Some eighteenthcentury metals". Journal of Chemical Education 9: 22.

5. Bibcode: 1932JChEd...9...22W. 
6. Lee B, Alsenz R, Ignatiev A, Van Hove M, Van Hove MA (1978) "Surface structures of the two allotropic phases of cobalt". Physical Review B 17: 1510-1520. Bibcode: 1978PhRvB..17.1510L.

7. "Properties and Facts for Cobalt" (2008) American elements.

8. Cobalt, Centre d'Information du Cobalt, Brussels (1966) Cobalt 45.

9. Michel R, Nolte M, Reich M, Löer F (1991) "Systemic effects of implanted prostheses made of cobalt-chromium alloys". Archives of Orthopaedic and Trauma Surgery 110: 61-74.

10. Cobalt Development Institute.

11. Smith IC, Carson BL (1981) Trace metals in the environment. Ann Arbor, MI: Ann Arbor Science Publishers.

12. Meranger JC, Subramanian KS, Chalifoux C (1981) Metals and other elements: Survey for cadmium, cobalt, chromium, copper, nickel, lead, zinc, calcium, and magnesium in Canadian drinking water supplies. J Assoc Off Anal Chem 64: 44-53.

13. Rubin ES (1999) Toxic releases from power plants. Environ Sci Technol 33:3062- 3067

14. Buchholz BA, Landsberger S (1995) Leaching dynamics studies of municipal solid waste incinerator ash. J Air Waste Manage Assoc 45: 579-590

15. Mumma RO, Raupach DC, Sahadewan K (1991) Variation in elemental composition of municipal refuse incinerator ashes with time of sampling. Chemosphere 23: 391-395.

16. Evans GJ, Tan PV (1998) The fate elements in residential composters. Arch Environ Contam Toxicol 34: 323-329.

17. Gutenmann WH, Rutzke M, Kuntz HT (1994) Elements and polychlorinated biphenyls in sewage sludge of large cities in the United States. Chemosphere 28: 725-728.

18. Raven KP, Loeppert RH (1997) Trace element composition of fertilizers and soil amendments. J Environ Qual 26: 551-557.

19. Fergusson JE, Ryan DE (1984) The elemental composition of street dust from large and small urban areas related to city type, source and particle size. Sci Total Environ 34: 101-116.

20. Davis JE, Fields JP (1958) Experimental production of polycythemia in humans by administration of cobalt chloride. Proc Soc Exp Biol Med 99: 493-495.

21. Bonenfant JL, Auger C, Miller G (1969) Quebec beer-drinkers myocardosis: pathological aspects. Ann N Y Acad Sci 156: 577-582.

22. Kesteloot H, Roelandt J, Willems J (1968) An enquiry into the role of cobalt in the heart disease of chronic beer drinkers. Circulation 37: 854-864.

23. Morin Y, Daniel P (1967) Quebec beer-drinkers' cardiomyopathy: Etiological considerations. Can Med Assoc J 97: 926-928.

24. Sullivan JF, Egan JD, George RP (1969) A distinctive myocardiopathy occurring in Omaha, Nebraska:Clinical aspects. Ann N Y Acad Sci 156: 526-543.

25. Alexander CS (1969) Cobalt and the heart. Ann Intern Med 70: 411- 413.

26. Alexander CS (1972) Cobalt-beer cardiomyopathy: A clinical and pathological study of twenty-eight cases. Am J Med 53: 395-417.

27. Clyne N, Hofman-Bang C, Haga Y (2001) Chronic cobalt exposure affects antioxidants and ATP production in rat myocardium. Scand J Clin Lab Invest 61: 609-614.
28. Morin Y, Tetu A, Mercier G (1971) Cobalt cardiomyopathy: Clinical Aspects. Br Heart J 33: 175-178.

29. Newman LS (1998) Metals that cause Sarcoidosis. Semin Respir Infect 13:212-220.

30. Zanelli R, Barbic F, Migliori, Michetti G (1994) Uncommon evolution of fibrosing alveolitis in a hard metal grinder exposed to cobalt dusts. Sci Total Environ 150:225-229.

31. Shirakawa T, Kusaka Y, Fujimura N, Goto S, Kato M, et al. (1989) Occupational asthma from cobalt sensitivity in workers exposed to hard metal dust. Chest 95: 29-37.

32. Roy PE, Bonenfant JT, Turcot L (1968) Thyroid changes in cases of Quebec beer drinkers myocardosis. Am J Clin Pathol 50: 234-239.

33. Kriss JP, Carnes WH, Ross RT (1955) Hypothyroidism and thyroid hypoplasia in patients treated with cobalt. JAMA 157: 117-121.

34. Chamberlain JL (1961) Thyroid enlargementprobably induced by cobalt. A report of 3 cases. J Pediatr 59: 81-86.

35. Little JA, Sunico R (1958) Cobalt-induced goiter with cardiomegaly and congestive failure. J Pediatr 52: 284-288.

36. Sederholm T, Kouvalainen K, Lamberg BA (1968) Cobalt-induced hypothyroidism and polycythemia in lipoid nephrosis. Acta Med Scand 184: 301-306.

37. Washburn TC, Kaplan E (1964) Cobalt therapy and goiter. Clin Pediatr 3: 89-92.

38. Veien NK, Hattel T, Justesen O (1987) Oral challenge with nickel and cobalt in patients with positive patch tests to nickel and/or cobalt. Acta Derm Venereol (Stockh) 67: 321-325.

39. Licht A, Oliver M, Rachmilewitz EA (1972) Optic atrophy following treatment with cobalt chloride in a patient with pancytopenia and hypercellular marrow. Isr J Med Sci 8: 61-66.

40. Soo K Ng, Ebneter A, Gilhotra JS (2013) Hip-implant related chorioretinal cobalt toxicity. Indian J Opthalmol 61: 35-37.

41. Apel W, Stark D, Stark A, O'Hagan S, Ling J (2013) Cobaltchromium toxic retinopathy case study 126: 69-78.

42. Mucklow ES, Griffin SJ, Delves HT (1990) Cobalt poisoning in a 6 year old. The Lancet 335: 981.

43. Llena JF, Cespedes G, Hirano A (1976) Vascular alterations in delayed radiation necrosis of the brain. Arch Pathol Lab Med 100: 531-534.

44. Fishman ML, Bean SC, Cogan DG 1976) Optic atrophy following prophylactic chemotherapy and cranial radiation for acute lymphocytic leukemia. Am J Ophthalmol 82: 571-576.

45. Sanyal B, Pant GC, Subrahmaniyam K (1979) Radiation myelopathy J Neurol Neurosurg Psychiatry 42: 413-418.

46. Johansson S, Svensson H, Denekamp J (2000) Timescale of evolution of late radiation injury after postoperative radiotherapy of breast cancer patients. Int J Radiat Oncol Biol Phys 48: 745-750.

47. Faroon OM, Abadin $\mathrm{H}$, Keith S (2004) Toxicological profile for cobalt. US Department of Health and Human Services. Public Health Service, Agency for Toxic Substances and Disease Registry.

48. Sauls DL, Wolberg AS, Hoffman M (2002) Elevated plasma homocysteine leads to alterations in fibrin clot structure and stability: Implications for the mechanism of thrombosis in hyperhomocysteinemia. Journal of Thrombosis and Haemostasis 1: 300-306. 